\title{
Structural Elucidation and Antimicrobial Analysis of Chloroform Leaf Extract of Acanthus montanus
}

\author{
*Ikezu U.J.M. ${ }^{1}$, Ajiwe V.I.E. ${ }^{2}$, Ilozue N.M. ${ }^{1}$, Chukwukanne C. ${ }^{2}$ \\ Department of Chemical Sciences, Tansian University Umunya, Anambra State, Nigeria. \\ Department of Industrial Chemistry, NnamdiAzikiwe University Awka, Anambra State, Nigeria.
}

\begin{abstract}
Leaf extract of Acanthus montanus of the family Acanthacea which is widely used traditionally for medicinal purposes was worked on to elucidate the structure of the pharmaceutical active ingredients. Thin layer chromatography of chloroform leaf extract showed one spot with $R f$ value of 0.78 . The extract was subjected to spectroscopic analysis using FTIR, Uv-Visible, $H^{1} N M R, C^{13} N M R$ and GCMS instruments. The suggested structure for the chloroform leaf extract was 4-butyl acrylate (3,5-Di-tert-butyl-4-hydroxy phenyl). Antibacterial and Antifungal activity of the pure extract was carried out extract using 10 bacteria species (gram positive and gram negative) such as Salmonella sp, Staphylococcus aureus, Bacillus sp, Proteus vulgaris, S. albus, Enterobacter aerogenes, Pseudomonas pyocyania, Streptococcus sp, Klebsiella aerogenes and fungal cultures such as Aspergillus flavus, Aspergillus niger, Candida alblicans with zone of inhibition ranging between 8 and 22mm. This antimicrobial result was compared with that of some standard antibiotics and was discovered to be potent and effective in both fungi and bacteria.

Keywords: Fungi, Bacteria, Antimicrobial, Antibiotics and Structural elucidation.
\end{abstract}

\section{Introduction}

Since the dawn of human civilization, medicinal plant constitutes the basis of primary health care for the majority of the population. Many plants synthesize substances that are useful in human and animals nutrition. The use of plants as medicine predates written human history [1]. All plants produce chemical compounds as part of their normal metabolic activities. The development in the field of modern medicine temporarily subdued the traditional herbal medicine but has now stayed a comeback and herbal renaissance is blooming across the world [2, [3]. Green medicine is healthier, safer and harmless than synthetic ones. The acceptance of traditional medicine as an alternative form of health care and development of microbial resistance to the available antibiotics led researchers to investigate the antimicrobial activity of plant [4,5]. In recent years there has been renewed interest in natural medicines that are obtained from plant parts or extracts. On the order of $40 \%$ or more of the pharmaceuticals currently used in western countries are derived from natural sources [6]. Medicinal plant in addition to providing the basic for between 30 and $40 \%$ of today's conventional drugs, the medicinal and curative properties of various plants are also employed in herbal supplements, botanical, neutraceuticals and teas [7]. Medicinal plants are particularly important to rural residents who are not well served by formal health care systems. Studies on the medicinal values of some Nigeria plants have attracted so much attention from various professionals all over the world including Nigeria. This has lead the Federal Government of Nigeria to adopt the National Policy on traditionalmedicine in 1997 [8,9]. The plant studied in this research (Acanthus montanus) a perennial herb from the family Acanthaceae also known as mountain thistle or alligator plant is a striking small shrub with sparse branches and soft stem [10]. Native of West Africa and very popular in Southern Nigeria where it is used ethnomedically for the treatment of cough, inflammatory and infectious diseases. The root is acclaimed highly by various society of Africa as an effective remedy for abscesses while the leaf extract had been used to treat cases of threatened abortion, abdominal pains, pains of acute gastritis and believe to be antacid [11].

The objective of this study was to extract the phytochemical constituents in the leaf of the plant and elucidate the structure using spectroscopic techniques. The antimicrobial activity of each fraction was determined and compared with some existing antibiotics.

\section{Materials And Methods}

The leaves were air dried under laboratory conditions for seven days, ground into powdered form using manual blender. Phytochemical tests were carried out by methods outlined by Jiofack et al. [7].

\section{EXTRACTION AND ISOLATION OF DIFFERENT CLASSES OF NATURAL PRODUCTS}

$500 \mathrm{~g}$ of the pulverized leaves were measured into a container, chloroform was added and the mixture was homogenized for 5 minutes, allowed to stand for $24 \mathrm{~h}$ and filtered. The filtrates were concentrated to one tenth volume in water bath at temperature below $40^{\circ} \mathrm{C}$ acidified with $2 \mathrm{ml} \mathrm{H}_{2} \mathrm{SO}_{4}$ and extracted subsequently 
with chloroform. The chloroform extract was dried by evaporation giving rise to moderately polar extract (terpenoids and phenolics). The obtained extract was analyzed directly by thin layer chromatography to determine the number of components and it recorded one spot with $\mathrm{Rf}$ value of 0.78 . The fraction was further subjected to FTIR,Uv-Visible, $\mathrm{H}^{1} \mathrm{NMR}, \mathrm{C}^{13} \mathrm{NMR}$ and GCMS to elucidate the structure of the component in the $\mathrm{CHCl}_{3}$ leaf extract.The antimicrobial activity of the chloroform leaf extract was then carried out with 10 bacteria and three fungi. The microbial activity of the Chloroform extract was further compared with existing commercial antibiotics. The method used for microbial analysis was the punch agar diffusion method [3].

\section{Results}

Table 1. Results of the FTIR Spectroscopic Analysis of the Pure $\mathrm{CHCl}_{3}$ Leaf Extract.

\begin{tabular}{|l|l|}
\hline Wave band cm & Description \\
\hline 3244.38 & OH stretch of aromatics \\
2921.29 & CH stretch of alkanes and aromatics \\
2856.67 & \\
& \\
1725.38 & C=O stretch of esters and ketones \\
1459.20 & C=C stretch of aromatics and alkanes \\
1375.29 & C-H in plane bend of alkenes \\
1251.84 & C-O stretch of esters and ketones \\
1183.30 & \\
1101.39 & \\
1061.85 & C-O deformation of ketones and esters \\
976.01 & CH deformation of alkyl groups \\
753.23 & CH bend of alkene \\
721.40 & CH bend (ortho) of aromatics \\
& CH bend of disubstituted alkenes
\end{tabular}

Table 2. UV- Visible Spectrum Results for Pure $\mathrm{CHCl}_{3}$ Leaf Extract

\begin{tabular}{|c|c|c|}
\hline Wave length $(\lambda \mathrm{nm})$ & Bond & Transition \\
\hline 891.80 & & \\
\hline 883.00 & $-\mathrm{C}=\mathrm{O}$ & $\mathrm{n} \rightarrow \pi^{*}$ \\
\hline 807.50 & $-\mathrm{C}=\mathrm{O}$ & $\mathrm{n} \rightarrow \Pi^{*}$ \\
\hline 739.00 & $\mathrm{C}=\mathrm{C}$ & $\mathrm{n} \rightarrow \Pi^{*}$ \\
\hline 656.50 & $\mathrm{C}=\mathrm{C}$ & $\pi \mapsto \pi^{*}$ \\
\hline
\end{tabular}

Table 3. Summary of the $\mathrm{H}^{1}$ and $\mathrm{C}^{13} \mathrm{NMR}$ results of the $\mathrm{CHCl}_{3}$ Leaf Extract

\begin{tabular}{|c|c|c|c|c|c|}
\hline $\begin{array}{l}\mathrm{H}^{\mathrm{I} \delta}(\mathrm{ppm}) \text { and } \\
\text { multiplicity }\end{array}$ & Coupling constant & Types of proton & $\mathrm{C}^{13} \delta(\mathrm{ppm})$ & Types of carbon & Position of carbon \\
\hline $7.22(\mathrm{~s})$ & 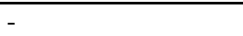 & $\mathrm{ArOH}$ & 77.66 & $\mathrm{C}=\mathrm{O}$ & 1 \\
\hline $3.90(\mathrm{t})$ & 10.27 & $\mathrm{R}-\mathrm{COO}-\mathrm{C}-\mathrm{H}$ & 77.22 & $\mathrm{C}-\mathrm{O}$ & 2 \\
\hline 2.29 (d) & 9.47 & Ar-C-H & 77.02 & $\mathrm{C}-\mathrm{OH}$ & 3 \\
\hline $1.64(\mathrm{~d})$ & 8.40 & $\mathrm{C}=\mathrm{C}-\mathrm{CH}_{3}$ & 76.39 & $\mathrm{C}$ & 4 \\
\hline $1.34(\mathrm{~d})$ & 55.52 & $\mathrm{R}_{2} \mathrm{CH}_{2}$ & 33.94 & $\mathrm{C}=\mathrm{C}$ & 5 \\
\hline \multirow{15}{*}{$0.82(\mathrm{~d})$} & 16.34 & $\mathrm{RCH}_{3}$ & 31.92 & $\mathrm{C}=\mathrm{C}$ & 6 \\
\hline & & & 31.42 & $\mathrm{C}=\mathrm{C}$ & 7 \\
\hline & & & 30.16 & $\mathrm{C}=\mathrm{C}$ & 8 \\
\hline & & & 29.69 & $\mathrm{CH}$ & 9 \\
\hline & & & 29.61 & $\mathrm{CH}$ & 10 \\
\hline & & & 29.44 & $\mathrm{CH}$ & 11 \\
\hline & & & 29.37 & $\mathrm{CH}_{2}$ & 12 \\
\hline & & & 29.25 & $\mathrm{CH}_{2}$ & 13 \\
\hline & & & 29.12 & $\mathrm{CH}_{2}$ & 14 \\
\hline & & & 29.06 & $\mathrm{CH}_{2}$ & 15 \\
\hline & & & 24.89 & $\mathrm{CH}_{2}$ & 16 \\
\hline & & & 24.70 & $\mathrm{CH}_{3}$ & 17 \\
\hline & & & 22.69 & $\mathrm{CH}_{3}$ & 18 \\
\hline & & & 20.70 & $\mathrm{CH}_{3}$ & 19 \\
\hline & & & 14.13 & $\mathrm{CH}_{3}$ & 20 \\
\hline
\end{tabular}

FTIR spectrum (Table 1) supported the structure of $\mathrm{CHCl}_{3}$ leaf thus, $\mathrm{OH}$ stretch of aromatic was observed at $3244.38 \mathrm{~cm}^{-1}$ while $\mathrm{CH}$ stretch of alkanes and aromatics appeared at 2921.29 and $2856.67 \mathrm{~cm}^{-1} . \mathrm{C}=\mathrm{O}$ stretch of esters and ketones appeared at $1725.38 \mathrm{~cm}^{-1}$ whereas $\mathrm{C}=\mathrm{C}$ stretch of aromatics and alkenes appeared at $1459.20 \mathrm{~cm}^{-1}$ while $\mathrm{CH}$ in plane bend of alkenes was observed at $1375.29 \mathrm{~cm}^{-1} . \mathrm{C}-\mathrm{O}$ stretch of esters and ketones occurred at $1251.84 \mathrm{~cm}^{-1}$. C-O deformation of ketone and esters appeared at $1101.39 \mathrm{~cm}^{-1}$, CH deformation of alkyl groups appeared at $976.01 \mathrm{~cm}^{-1}$ while $\mathrm{CH}$ bend of aromatics occurred at $153.23 \mathrm{~cm}^{-1}$ and $\mathrm{CH}$ bend of disubstituted alkenes was observed at $721.40 \mathrm{~cm}^{-1}$. 
UV- Visible Spectrum (Table 2) supported the structure of $\mathrm{CHCl}_{3}$ pure extract with high $\mathrm{\lambda max}$ indicating high degree of unsaturation corresponding to phenolicsand their analogous that exhibit bathchromic shift. The absorption in visible region was very prominent.

$\mathrm{H}^{1} \mathrm{NMR}$ spectrum (Table 3) showed a phenolic proton at 7.22ppm while a triplet ester hydrogen was observed at $3.90 \mathrm{ppm}$. A duplet benzyl proton appeared at $2.29 \mathrm{ppm}$ whereas a duplet alkene hydrogen occurred at $1.64 \mathrm{ppm}$, equally a duplet methylene proton appeared at $1.34 \mathrm{ppm}$ while a duplet methyl hydrogen was observed at $0.82 \mathrm{ppm}$.

$\mathrm{C}^{13}$ NMR spectrum (Table 4) recorded 20 signals corresponding to 20 distinct carbon atoms.A carbonyl carbon atom occurred at $77.66 \mathrm{ppm}$ due to double bond while a carboxyl carbon was observed at 77.22ppm. A hydroxyl carbon appeared at 77.02ppm whereas four alkene carbon -carbon atoms appeared at 33.94, 31.92,31.42 and $30.16 \mathrm{ppm}$ respectively. Three methine carbon atoms were observed at 30.16, 29.69 and26.61 ppm while four methylene carbon atoms appeared at 29.44, 29.37, 29.25 and 29.12ppm respectively. Four methyl carbon atoms occurred at $24.70,22.69,20.70$ and 14.13 ppm respectively.

GCMS results gave one major fragment with butyl acrylate as the parent compound. The molecular mass is 332 with formular as $\mathrm{C}_{21} \mathrm{H}_{32} \mathrm{O}_{3}$ and suggested structure from instrument library is shown below.

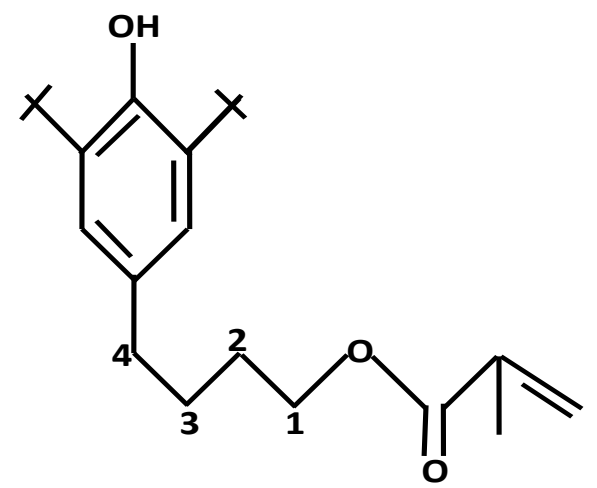

\section{4- (3,5-Di-tert-butyl-4-hydroxyphenyl) butyl acrylate}

These results suggested that $\mathrm{CHCl}_{3}$ leaf extract was a phenolic compound and a derivative of benzene. The result supported the ethnomedicinal use and antimicrobial results because butyl acrylate and their derivatives are used pharmaceutically as anticancer drugs [12].

Table 4. Result of Antibacterial and Antifungal Activities of the Pure Extract (B8) including Lincocin, Ammoxil and Augmentin
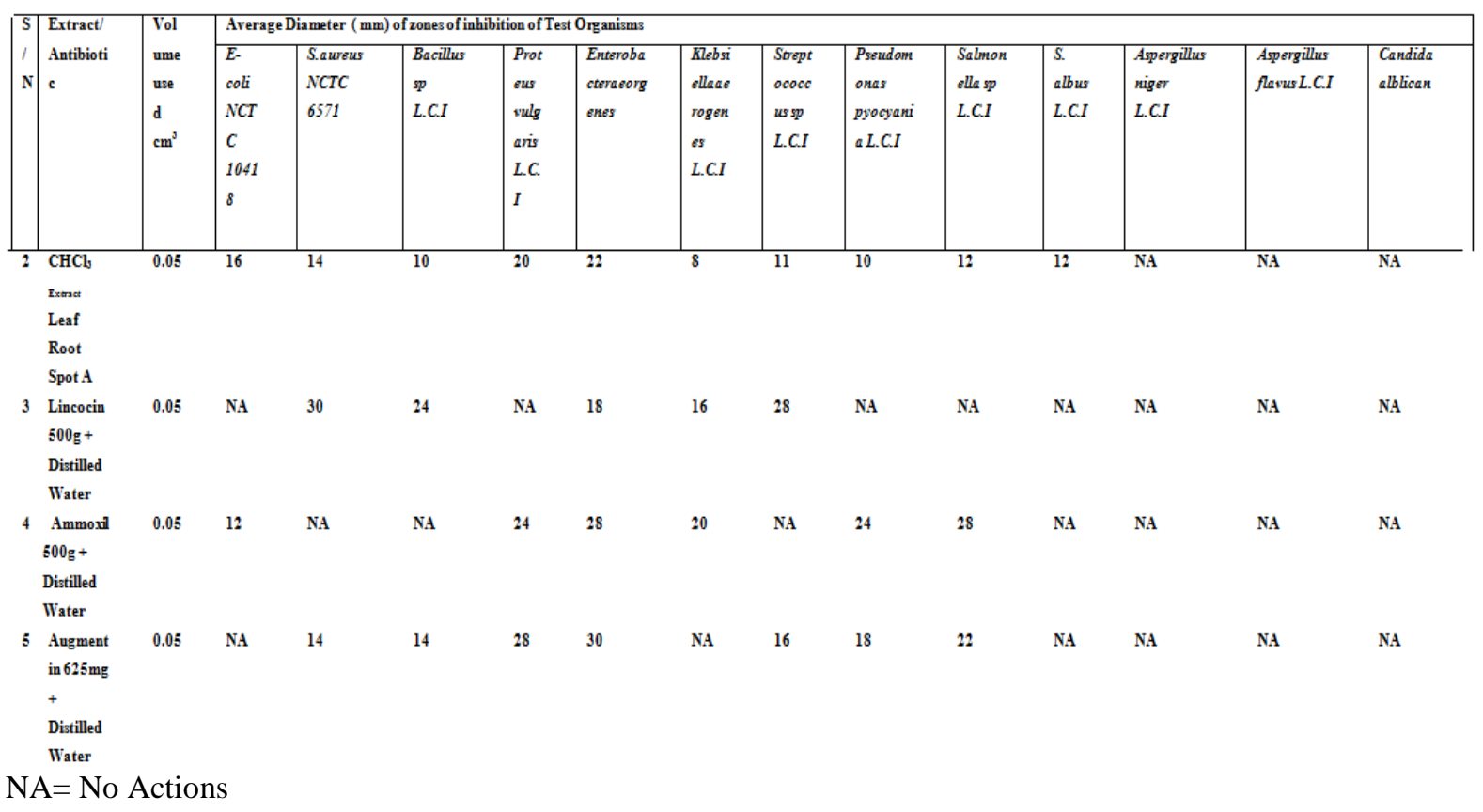
Table 5. Result of Minimum Inhibition Concentration (MIC) and Minimum Fungicidal Concentration(MFC)

\begin{tabular}{|c|c|c|c|c|c|}
\hline \multicolumn{6}{|c|}{ PRESENCE OR ABSENCE OF GROWTH OF TEST ORGANISM } \\
\hline Extract & Dilution & $\mathrm{Mg} / \mathrm{ml}$ & $\begin{array}{l}\text { Aspergillusniger } \\
\text { L.C.I }\end{array}$ & $\begin{array}{l}\text { Aspergillusflavus } \\
\text { L.C.I }\end{array}$ & $\begin{array}{l}\text { Candida } \\
\text { alblicans }\end{array}$ \\
\hline $\begin{array}{l}\mathrm{CHCl}_{3}-\mathrm{MeOH} \\
\text { Leaf } \\
\text { Control Tube } 8\end{array}$ & $\begin{array}{l}\text { Neat } \\
1: 2 \\
1: 4 \\
1: 8 \\
1: 16 \\
1: 32 \\
1: 64 \\
1: 128\end{array}$ & $\begin{array}{l}2.00 \\
1.00 \\
0.50 \\
0.25 \\
0.125 \\
0.0625 \\
0.0313 \\
0.0156\end{array}$ & $\begin{array}{l}- \\
- \\
- \\
+ \\
++ \\
++ \\
++ \\
-\end{array}$ & $\begin{array}{l}- \\
- \\
- \\
+ \\
++ \\
++ \\
++ \\
++ \\
+\end{array}$ & $\begin{array}{l}- \\
- \\
+ \\
++ \\
++ \\
++ \\
++ \\
++ \\
+\end{array}$ \\
\hline MIC & & & 0.0625 & 0.1250 & 0.2500 \\
\hline MFC & & & 0.1250 & 0.2500 & 0.5000 \\
\hline
\end{tabular}

L.C.I =Local Clinical Isolates

The sensitivity test on $\mathrm{CHCl}_{3}$ leaf extract showed that Enterobacteraerogenes was the most inhibited organism with diameter zone of inhibition [22.00mm] which was higher than that of Lincocin[18.00mm] but lower than that of Ammoxil [28.00mm] and Augmentin [30.00mm]. The diameter zones of inhibition of the extract for $E$. coli $[16.00 \mathrm{~mm}]$ was higher than that of Lincocin (no action), Ammoxil [12.00mm] and Augmentin [no action]. $\mathrm{CHCl}_{3}$ leaf extract was equally active against organismslike Pseudomonas pyocyania, Salmonella sp, S.albus, Streptococcus sp, S.aureus, E. coli, and Klebsiellaaerogenes, whereas Lincocin , Ammoxil and Augmentin recorded no action.The extract was not active on fungi like Aspergillusniger, Aspergillusflavus and Candida alblicans just like Ammoxil, Augmentin and Lincocin. These results confirmed that the $\mathrm{CHCl}_{3}$ leaf extract might be effective in treatment of diseases caused by test bacteria thus supporting the use of the plant in the cure of some diseases by trado-medical practitioners [11,12]. The MIC range of the extract in the ten test bacteria was $0.0625 \mathrm{mg} / \mathrm{ml}$ to $0.2500 \mathrm{mg} / \mathrm{ml}$ showing that even at a very low concentration, the extract was highly bactericidal.

\section{Conclusion}

This study scientifically validates the use of the $\mathrm{CHCl}_{3}$ leaf extract of Acanthus montanusas a potent Antimicrobial agent. The $\mathrm{CHCl}_{3}$ extract has been shown to be effective against some test organism signifying that the plant could be used in the cure and management of the various diseases caused by the test organism and can serve as potential raw material for new or known antibiotics.

\section{References}

[1] Ajiwe, V.I.E., N.N. Dimonyejiaku, A.C. Ajiwe, A.J. Chinwuba and N.M.Chendo, 2008.Preliminary Study on the Pharmaceutical Constituents of Emilia sonchifolia leaf. Anachem Journal, 2(2),302-309.

[2] Balick, M. J. and P. C., Alan, 1996.Plants That Heal In their Plants, People and Culture: the Science of Ethnobotany,Scientific American Library, New York, pp.25-61.

[3] Bryant, M.C., , 1972. Antibiotic and their Laboratory Control, 2nd Edition, Butter Worth, London, P.85.

[4] Dey , S., . 2006.Pharmaceuticals From Plants Indian Express Newspaper (Mumbai) Ltd via Express pharma. http://en.wiliversity.org/wiki/chemistry and its socioeconomic impact . Retrived 11/9/011.

[5] Finar, I.L., 2005.Organic Chemistry , Vol 2. Stereochemistry and Chemistry of Natural Products, $5^{\text {th }}$ Edition,PearsonPublishers,India,pp. 354-793.

[6] Harborne, J.B,1998. Phytochemical Method,A Guide to Modern Techniques of Plant Analysis, $3^{\text {rd }}$ Edition, Chapman and Hall, An Imprint of Thompson Science 2-6 Boundary row, London, Uk, pp 1- 290.

[7] Jiofack, I., C. Anyissi, N. Fokunang, V Gueje and E.Kemeuze, 2009. Ethnobotany and Phytomedicine of the upper Nyong valley forest in Cameroon, African Journal of Pharmacy and Pharmacology, 3 (4), 144-150.

[8] Kevin, S., Butyl acrylate ,The Synthesis of AmphiphilicDiblock Copolymer. www.slideboom.com.Retrived 4/2/2012.

[9] Medicinal Plant Facing Threats. BBC News ,2008.http//news.bbc.co.uk/2/hi/health/7196702.stm. Retrived 17/6/2011.

[10] Nation onlineWorld Population by Continent and Countries"http ://www. Nationonline.org/oneworld/world population .htm .Retrived 14/7/2011.

[11] Strivastava, L.L. and M.N .Viet, 1996.Medicinal Plants. An Expanding Role in Development World Bank, Technical Paper, No 320 Washington DC,20433, USA . pp1-2

[12] Thenmozhi, M., P.K. Bhavya and S. Rajeshwari, 2011. Compound Identification Using HPLC and FTIR in Eclipta alba and Emilia sonchifolia, International journal of Engineering Sciences and technology (IJEST) 3(1) 292-298 